\title{
Phytochemical Constituents of Some Nigerian Plants
}

\author{
Ameh, G. I. and Eze, C. S. \\ Department of Applied Biology and Biotechnology, Enugu State University of Science and Technology, Enugu, \\ Nigeria.
}

Corresponding author: Ameh, G. I. Department of Applied Biology and Biotechnology, Enugu State University of Science and Technology, Enugu, Nigeria.

\begin{abstract}
Assessment of the distribution of alkaloids, saponins, tannins, glycosides, phenols, steroids and flavonoids in ten Nigerian plants belonging to different families was carried out. All the plants investigated contained flavonoids but lacked steroids. Apart from Afzelia africana and Detarium microcarpum, the rest contained alkaloids. Glycosides were present in all except Gongronema latifolium. Phenols occurred in all the plants except A. africana, D. microcarpum and Azadirachta indica. Saponins were absent only in G. latifolium, A. indica and Cola nitida while tannins occurred only in Piper guineense, G. latifolium, Myrianthus arboreus, $A$. indica, and C. nitida. In quantitative estimation of each phytochemical present in the plants, C. nitida showed the highest percentage alkaloids (7.76\%) and Treculia africana the highest percentage saponins (4.24\%) while the highest percentage tannins was recorded in A. indica. $T$. africana had the highest percentage glycosides (24\%) and phenols (48\%) while $A$. indica and $C$. nitida showed the highest percentages of flavonoids. The medicinal uses of the plants understudy were reviewed.
\end{abstract}

Keywords: Alkaloids, Saponins, Tannins, Glycosides, Phenols, Steroids, Flavonoids, Nigerian plants

Introduction

Knowledge of the chemical constituents of plants is important for the discovery of therapeutic agents. The use of plants for treatment of different ailments is as old as mankind. According to Makhubu (1998), the use of plants for medicinal purpose was recorded in Pharmacopoeia of Emperor Shen Nung of China between 273 to $300 \mathrm{BC}$. This is an indication that man was aware of the medicinal properties of some plants about 300 years BC. Medicinal plants contain physiologically active principles that over the years have been used in traditional medicine (Adebajo et al., 1983). It was reported by Banso and Olutimayin (2001) that plants contain a wide variety of active principles. The most important of these bioactive principles include alkaloids, tannins, flavonoids, steroids, glycosides and phenolic compounds.

Piper guineense Schum and Thonn, Afzelia africana Sm.ex Pers, Pterocarpus soyauxi Jacq, Mucuna soloanei Adams, Gongronema latifolium Benth, Myrianthus arboreus P.Beav, Detarium microcarpum Guill. and Perr., Treculia africana Decne, Azadirachta indica $A$. Juss and Cola nitida (Vent) Schott and Endl are used in herbal medicine in Nigeria. The various uses of these plants in traditional medicine are reviewed in Table 1. Since these plants are all used in herbal medicine, there is the need to assay their chemical constituents in order to ascertain those bioactive constituents that confer on them medicinal value.

\section{Materials and Methods}

Collection and identification of plant materials: The leaves or seeds of $P$. guineense, $A$. africana, $P$. soyauxi, M. soloanei, G. latifolium, $M$. arboreus, $D$. microcarpum, $T$. africana, $A$. indica and $C$. nitida were collected from forests located in Eastern part of Nigeria and used for this study. The plant samples were authenticated by Prof. J.C. Okafor, a Consultant Taxonomist of Fame Agricultural Centre, Enugu.

Preparation of plant materials: The plant materials were air-dried and pulverized in a grinding machine into a fine form. The aqueous extract of each sample was prepared by soaking $20 \mathrm{~g}$ of the powdered sample in $100 \mathrm{ml}$ of distilled water and ethanol respectively for $24 \mathrm{hrs}$. The extract was filtered using Watchman No. 1 filter paper and stored in a plastic container for further use.

Phytochemical screening: The phytochemical test on the aqueous extracts was carried out according to the procedures and methods described by Trease and Evans (1989), Soforowa (1993) and Harbone (1994)

Qualitative test: This assay was carried out to determine the presence of alkaloids, saponins, flavonoids, tannins, phenols, glycosides and steroids in the aqueous extract of each plant.

Test for alkaloids: One milliliter of each extract was added to $0.5 \mathrm{ml}$ of Mayer's reagent. A cloudy milky precipitate indicates the presence of alkaloids.

Test for saponins: Three milliliters of each extract was boiled for 1 minute and added $2 \mathrm{ml}$ of distilled water, shaken vigorously and observed for a stable persistent froth. 3 drops of olive oil was added to the frothing and shaken vigorously for the formation of emulsion.

Test for flavonoids: Three millilitres of each extract was added to $10 \mathrm{ml}$ of distilled water and 1 $\mathrm{ml}$ of $10 \%$ sodium hydroxide solution. A yellow colouration indicated the presence of flavonoids. 
Test for tannins: Two millilitres of each extract was boiled gently for 2 minutes and 3 drops of ferric chloride added. A brownish or blue-black colouration indicated the presence of tannins.

Test for phenols: A small portion of each extract was mixed with $1 \mathrm{ml}$ of distilled water and a few drops of $5 \%$ sodium hydroxide. Orange colouration indicates the presence of phenols.

Test for glycosides: One millilitre of $2 \%$ dinitrosalicyclic acid (DNS) and $1 \mathrm{ml}$ of $5 \%$ sodium hydroxide were added to $1 \mathrm{ml}$ of each extract. A brick red precipitate indicated the presence of glycosides.

Test for steroids: Five drops of concentrated sulphuric acid were added to each extract and shaken to form a uniform solution. Formation of dark-red colouration indicated the presence of steroids.

Quantitative test: The quantitative test was done to ascertain the amount of each chemical constituent detected in the aqueous extract of each plant.

Preparation of fat-free sample: Two grammes (2 g) of each sample was defatted with $100 \mathrm{ml}$ of diethyl ether using Soxhlet apparatus for $2 \mathrm{hrs}$.

Determination of percentage alkaloid: Five grammes of the defatted sample was put into a 250 $\mathrm{ml}$ beaker, $200 \mathrm{ml}$ of $10 \%$ acetic acid in ethanol was added and the beaker covered. This was allowed to stand for $4 \mathrm{hrs}$, filtered and the extract concentrated to one quarter of its original volume using a water bath. Concentrated ammonium hydroxide was added drop wise until precipitation was completed. The whole solution was washed with ammonium hydroxide and filtered. The residue containing the alkaloids was dried and weighed. Percentage alkaloid was calculated as follows: \% Crude alkaloids $=$ Weight of residue $/$ Weight of sample $x$ 100.

Determination of percentage flavonoid: Ten grammes $(10 \mathrm{~g})$ of the sample was extracted repeatedly with $100 \mathrm{ml}$ of $80 \%$ aqueous methanol at room temperature. The solution was filtered using Watchman No. 1 filter paper. The filtrate was then transferred into a platinum crucible and evaporated to dryness over a water bath, and weighed (Boham and Kocipai, 1974). Percentage flavonoid was calculated as follows: \% Flavonoid $=$ Weight of residue / Weight of sample $\times 100$.

Determination of percentage tannin: Into a 250 $\mathrm{ml}$ conical flask, $0.5 \mathrm{~g}$ of samples was placed and mixed with $50 \mathrm{ml}$ of distilled water. The mixture was shaken for $1 \mathrm{hr}$ in a mechanical shaker, filtered into a $50 \mathrm{ml}$ volumetric flask and made up to the mark with distilled water. Then $5 \mathrm{ml}$ of the filtrate, $5 \mathrm{ml}$ of $0.1 \mathrm{~g}$ tannic acid solution and $1 \mathrm{ml}$ of distilled water (blank) were measured into three different volumetric flasks and incubated for 30 minutes at a temperature of $20-30^{\circ} \mathrm{C}$. The absorbance was measured using red filter at a wavelength of $760 \mathrm{~nm}$ in spectrophotometer (Van-Burden and Robinson, 1981). Percentage tannin was determined as follows: Tannin in Mg/100 $=X-Z / Y-Z$, where $X$ $=$ absorbance of $5 \mathrm{ml}$ of the extract, $Y=$ absorbance of $5 \mathrm{ml}$ of tannic acid solution and $\mathrm{Z}=$ absorbance of $1 \mathrm{ml}$ of blank.

Determination of percentage glycoside: Five grammes of the sample was added to $2 \mathrm{ml}$ of $20 \%$ solution of dinitrosalicyclic acid in methanol and boiled for 2 minutes. The mixture was filtered and the residue which was the glycosides was dried, cooled and weighed. Percentage glycoside was calculated as follows: \% glycosides = Weight of residue / Weight of sample $x 100$.

Determination of percentage total phenol: The fat-free sample was boiled with $50 \mathrm{ml}$ of ether for the extraction of the phenolic component for 15 minutes. $5 \mathrm{ml}$ of the extract was pipetted into a 50 $\mathrm{ml}$ flask and then $10 \mathrm{ml}$ of distilled water was added. $2 \mathrm{ml}$ of ammonium hydroxide solution and 5 $\mathrm{ml}$ of concentrated amylalcohol were also added. The sample was made up to mark with distilled water and left to react for 50 minutes for colour development. This was measured at $505 \mathrm{~nm}$ using a spectrophotometer. The concentration obtained at the stated absorbance was traced using phenol standard graph. Percentage total phenol was calculated as follows: \% total phenol = Concentration / Weight of sample x 100 .

Determination of percentage saponin: Twenty grammes $(20 \mathrm{~g})$ of the sample was weighed and soaked for $24 \mathrm{hrs}$ with $100 \mathrm{ml}$ of $20 \%$ ethanol and $80 \mathrm{ml}$ of distilled water. The sample was resoaked with $40 \mathrm{ml}$ of $20 \%$ ethanol and filtered after 45 minutes. The filtrate was concentrated to $40 \mathrm{ml}$ by heating in a water bath. Impurities and pigments were removed using diethyl ether, with separatory funnel. Four grammes of sodium chloride was added to the sample, followed by hydrochloric acid dropwise to bring the $\mathrm{pH}$ to 4.5 using a universal $\mathrm{pH}$ indicator. $90 \mathrm{ml}$ of $\mathrm{n}$-butanol was added. Ten millilitres of $50 \%$ aqueous $\mathrm{NaCl}$ was added twice. The whole solution was put in a beaker of known weight and heated to dryness. The percentage saponin was calculated as follows: $\%$ Saponin = Z / Sample weight $\times 100$. Where $Z$ (weight of residue) $=$ $Y-X, X=$ weight of empty beaker and $Y=$ weight of empty beaker + sample after drying.

\section{Results}

This study has revealed the distribution of some bioactive constituents in the plant samples. Tables 2 and 3 show the phytochemical characters of the ten plants studied. All the plants contained flavonoids but lacked steroids. Apart from $A$. africana, and $D$. microcarpum, the rest contained alkaloids. Glycosides were present in all except $G$. latifolium. Phenols occurred in all the plants except $A$. africana, $D$. microcarpum and $A$. indica. Saponins were absent only in $G$. latifolium, $A$. indica and $C$. nitida. 
Table 1: Review of medicinal uses of the study plants

\begin{tabular}{|c|c|c|c|}
\hline Species & Family & Traditional Use & Reference \\
\hline$P$. guineense & Piperaceae & $\begin{array}{l}\text { Vegetable and flavouring of soup, } \\
\text { treatment of gonorrhea and cough }\end{array}$ & Okwu (2001) \\
\hline A. africana & Caesalpinaceae & $\begin{array}{l}\text { Soup seasoning and thickening, } \\
\text { treatment of gonorrhea and stomach } \\
\text { troubles }\end{array}$ & $\begin{array}{l}\text { Kerharo and } \\
\text { Bouquet (1971) }\end{array}$ \\
\hline P. soyauxi & Fabaceae & $\begin{array}{l}\text { Vegetable, treatment of skin diseases } \\
\text { and fungal infections }\end{array}$ & $\begin{array}{l}\text { Oteng-Gyuna and } \\
\text { Mbachu (1987) }\end{array}$ \\
\hline M. soloanei & Papillionaceae & $\begin{array}{l}\text { Vegetable, food, lowers blood } \\
\text { cholesterol }\end{array}$ & $\begin{array}{l}\text { Mohan and } \\
\text { Janardhanan, } \\
\text { (1995) }\end{array}$ \\
\hline G. latifolium & Asclepiadaceae & $\begin{array}{l}\text { Vegetable, stimulate appetite, treatment } \\
\text { of cough, diabetes, and as laxative }\end{array}$ & Gills (1992) \\
\hline M. arboreus & Moraceae & $\begin{array}{l}\text { Vegetable, treatment of dysentery, } \\
\text { diarrhea and vomiting }\end{array}$ & Hill (2000) \\
\hline D. microcarpum & Caesalpinaceae & $\begin{array}{l}\text { Food, vegetable, thickening of soup, } \\
\text { treatment of rheumatism, stomach ache, } \\
\text { dysentery and diarrhea }\end{array}$ & $\begin{array}{l}\text { Gril and Isasa } \\
(1997)\end{array}$ \\
\hline T. africana & Moraceae & $\begin{array}{l}\text { Food, treatment of cough and as } \\
\text { laxative }\end{array}$ & Burkill (1984) \\
\hline A. indica & Meliaceae & $\begin{array}{l}\text { Treatment of malaria, diabetes, } \\
\text { rheumatism and digestive disorders }\end{array}$ & Adeninya (1993) \\
\hline C. nitida & Sterculiaceae & $\begin{array}{l}\text { Stimulant, counteracts fatigue, } \\
\text { suppresses thirst and hunger }\end{array}$ & $\begin{array}{l}\text { Nickalls (1986) } \\
\text { Sundstrom (1966) }\end{array}$ \\
\hline
\end{tabular}

Table 2: Qualitative analysis of the phytochemicals present in the plants understudy

\begin{tabular}{|c|c|c|c|c|c|c|c|}
\hline Species & Alkaloids & Saponins & Tannins & Glycosides & Phenols & Flavonoids & Steroids \\
\hline P. guineense & + & + & + & + & + & + & + \\
\hline A. Africana & - & + & - & + & - & + & - \\
\hline P. soyauxi & + & + & - & + & + & + & - \\
\hline M. soloanei & + & + & - & + & + & + & - \\
\hline G. Iatifolium & + & - & + & - & + & + & - \\
\hline M. arboreus & + & + & + & + & + & + & - \\
\hline D. microcarpum & - & + & - & + & - & + & - \\
\hline T. Africana & + & + & - & + & + & + & - \\
\hline A. indica & + & - & + & + & - & + & - \\
\hline C. nitida & + & - & + & + & + & + & - \\
\hline
\end{tabular}

+ Presence of constituent - absence of constituent

Table 3: Quantitative analysis of the phytochemicals present in the plants sample

\begin{tabular}{lcccccc}
\hline Species & $\begin{array}{c}\% \\
\text { Alkaloid }\end{array}$ & $\begin{array}{c}\% \\
\text { Saponin }\end{array}$ & $\begin{array}{c}\% \\
\text { Tannin }\end{array}$ & $\begin{array}{c}\% \\
\text { Glycoside }\end{array}$ & $\begin{array}{c}\% \\
\text { Phenol }\end{array}$ & $\begin{array}{c}\% \\
\text { Flavonoid }\end{array}$ \\
\hline P. guineense & 1.54 & 0.59 & 2.0 & - & 0.27 & 5.70 \\
A. africana & - & 0.25 & - & -4 & - & 4.95 \\
P. soyauxi & 0.82 & 0.17 & - & 4.4 & 5.2 & 2.39 \\
M. soloanei & 1.7 & 0.12 & - & 6.6 & 0.50 & 1.2 \\
G. latifolium & 0.96 & - & 0.01 & - & 0.23 & 5.29 \\
M. arboreus & 0.51 & 0.25 & 0.5 & 0.24 & 0.56 & 0.73 \\
D. microcarpum & - & 0.13 & - & 4.0 & - & 1.64 \\
T. africana & 0.88 & 4.24 & - & 24.0 & 48.0 & 1.56 \\
A. indica & 5.66 & - & 40.0 & 5.6 & - & 17.1 \\
C. nitida & 7.76 & - & 7.6 & 5.98 & 0.31 & 17.1 \\
\hline
\end{tabular}

- Absence of constituent.

Tannins occurred only in $P$. guineense, $G$. latifolium, $M$. arboreus, $A$. indica and $C$. nitida (Table 2). The quantitative estimation of the phytochemicals present in each plant sample is shown in Table 3. C. nitida had the highest percentage alkaloids $(7.76 \%)$, followed by $A$. indica $(5.66 \%)$ while $M$. arboreus contained the least yield of alkaloids $(0.51 \%)$. T. africana showed the highest percentage saponins (4.24\%), followed by $P$. guineense $(0.59 \%)$ while $M$. soloanei recorded the least yield $(0.12 \%)$. The highest percentage tannins was recorded for $A$. indica $(40.0 \%)$, followed by $C$. nitida $(7.6 \%)$, while $G$. latifolium had the lowest percentage of tannins $(0.01 \%)$. T. africana showed the highest percentage glycosides (24\%), followed by $M$. soloanei $(6.6 \%)$, while $M$. arboreus recorded the lowest yield $(0.24 \%)$. The highest percentage phenols was shown in $T$. africana (48\%), followed by $P$. soyauxi $(5.2 \%)$, while $G$. latifolium had the 
least $(0.23 \%)$. $A$ indica and $C$. nitida showed the highest percentage $(17.1 \%)$ of flavonoids, followed by $P$. guineense $(5.70 \%)$, while $M$. arboreus had the lowest percentage $(0.73 \%)$.

\section{Discussion}

The phytochemical constituents of some Nigerian plants were investigated. Phytochemical screening of these plants revealed the presence of alkaloids, saponins, tannins, glycosides, phenols and flavonoids in most of the plants. The presence of these phytochemicals in the various plant extracts accounts for their usefulness as medicinal plants. Mojab et al (2003) reported the presence of alkaloids, flavonoids, saponins and tannins in some Iranian plants. Edeoga et al (2005) also reported the presence of alkaloids, phenols, tannins, flavonoids and saponins in some medicinal plants. The absence of steroids in all the plant extracts is similar to the report of Banso and Adeyemo (2007) on Dracaena mannii.

The presence of flavonoids in all the plant species investigated establishes a good support to the use of these plants in herbal medicine and development of new drugs. Other secondary metabolites like alkaloids, phenols and saponins contained in these plant species are equally of interest in pharmacy. The presence of alkaloids, saponins, tannins, flavonoids and glycosides in these plants suggest that they possess antimicrobial properties. Leven et al. (1979) had linked the antimicrobial properties in plants to the presence of tannins, alkaloids, flavonoids and saponins. The percentage alkaloids, flavonoids and phenols obtained in this study were generally higher than those reported by Edeoga et al. (2005) on some medicinal plants. However the percentages they reported for saponins and tannins were higher than those recorded in this study.

The plants understudy can be seen to have potentials in herbal medicine and as source of useful drugs. Since these plants are used as food by the indigenous people of Nigeria, there is the need to investigate the food and mineral composition of these plants. Moreover, the antimicrobial properties of these plants should also be studied.

\section{References}

Adebajo, A.O., Adewumi, C.O. and Essien, E.E. (1983). Anti-infective agent of higher plants. International Symposuim of Medicinal plants. $5^{\text {th }}$ ed. University of Ife, Nigeria. pp152 - 158 .

Adeninya, I. (1993). Anti malarial activity of Nigerian neem leaves. Trans Royal Society Trop. Med. 4: 471

Banso, A. and Adeyemo, S.O. (2007). Phytochemical and antimicrobial evaluation of ethanolic extract of Dracaena mannii. Nig. J. Biotech. 18 (1-2): 27-32.

Banso, A. and Olutimayin, T. (2001). Phytochemical and antimicrobial evaluation of aqueous extracts of Daniella oliveri and Nauclea latifolia. Nig. J. Biotech. 12(1): 114-118.
Boham, B.A. and Kocipai, A.C. (1974). Flavonoids and condensed tannins from leaves of Hawaiian Vaccinium vaticulatum and V.calycinium. Pacific Sci. 48; 458-463.

Burkill, H.M. (1984). The useful plants of West Tropical Africa. Vol. 1. Royal Botanical Garden, Kiew. 436 pp.

Edeoga, H.O., Okwu, D.E. and Mbaebie, B.O. (2005). Phytochemical constituents of some Nigerian medicinal plants. African .J. Biotech. 4(7): $685-688$.

Gills, L.S. (1992). Ethnomedicinal uses of plants in Nigeria. University of Benin Press, Benin. $278 \mathrm{pp}$.

Gril, J.L. and Isasa, M.E.T. (1997). Nutritional composition of leaves and seeds of Detarium microcarpum. J. Food Sci. and Nut. 48: $321-321$.

Harbone, N.V. (1994). Phytochemical methods. A guide to modern techniques of plant analysis. $2^{\text {nd }}$ ed. Chapman and Hall, London. $425 \mathrm{pp}$.

Hill, A.F. (2000). Economic Botany. $2^{\text {nd }}$ ed. McGrew Hill Coy. Inc., New York. 560 pp.

Kerhero, B.B. and Bouquet, O. (1971). Important trees in Africa. Balbido Press, Accra, Ghana. 572 pp.

Leven, M., Vanden Berghe, D.A., Marten, I., Vilientnick, A. and Lomweas, E.C. (1979). Screening of higher plants for biological activity. Planta Medica 36:311 - 312.

Makhubu, L. (1998). Bioprospecting in an African context. Science 282: $41-42$.

Mohan, V.R. and Janardhanan, K. (1995). Chemical analysis and nutritional assessment of lesser known pulses of the genus Mucuna. Food Chem. 52: 275 - 280.

Mojab, F., Kamalinejad, M., Ghaderi, N. and Vahidipour, H.R. (2003). Phytochemical screening of some species of Iranian plants. Iranian J. Pharma. Research. 15: $77-82$.

Nickalls, R.W.D. (1986). The discovery that Cola nuts contain caffeine. Pharm. Journ. 236: 401-402.

Okwu, D.E. (2001). Evaluation of the chemical composition of indigenous species and flavouring agents. Global J. Pure Appl. Sci. 7(3): 455-459.

Oteng-Gyung, K. and Mbachu, J.I. (1987). Changes in the ascorbic acid content of some tropical leafy vegetables during traditional cooking and local processing. Food Chem. 23(1): 9-17.

Soforowa, A. (1993). Medicinal plants and traditional medicine in Africa. Chichester John, Wiley and Sons, New York. 256 pp.

Sundstrom, L. (1966). The cola nut functions in West African social life. Studia Ethnographia 26: 135-146.

Trease, G.E. and Evans, W.C. (1989). Pharmacognosy. $13^{\text {th }}$ ed. Bailliere Tindall Ltd, London. 389 pp.

Van-Burden, T.P. and Robinson, W.C. (1981). Formation of complexes between protein and tannic acid .J. Agric. Food Chem. 1: 76-79. 